Elżbieta Lorek*

Agnieszka Lorek**

Sylwia Stupik***

\title{
OCENA ROLI USŁUG EKOSYSTEMÓW MIEJSKICH W ZRÓWNOWAŻONYM ROZWOJU LOKALNYM
}

\section{Wprowadzenie}

Wzrost świadomości ekologicznej szczególnie w krajach wysoko rozwiniętych sprawił, iż coraz częściej w pracach dotyczących rozwoju na poziomie lokalnym, a zwłaszcza obszarów zurbanizowanych, uwagę poświęca się kwestiom środowiskowym. Problemy te są istotne zwłaszcza w związku z wyzwaniami cywilizacyjnymi, przed którymi stanęła obecnie ludzkość. Nowy paradygmat rozwoju wpływa na zmianę poszczególnych czynników determinujących procesy rozwojowe oraz zmianę kierunków polityki i zarządzania. Zgodnie z ideą zrównoważonego rozwoju (sustainable development) procesy rozwojowe powinny zachodzić na zasadzie harmonii pomiędzy czynnikami makrosystemu gospodarka - społeczeństwo - środowisko. Z uwagi na liczne powiązania pomiędzy poszczególnymi grupami czynników i występujące między nimi sprzężenia zwrotne ich znaczenie dla rozwoju jest równoważne. Proces ten ma miejsce na wszystkich poziomach podziału terytorialnego i obejmuje wszystkie sfery aktywności ludzkiej. Skuteczność i efektywność przedsięwzięć w skali kraju zależy od działań lokalnych, a efektywność w sferze gospodarczej zależy od działań podejmowanych w sferze społecznej i środowiskowej.

Wdrażanie zasad zrównoważonego rozwoju w polskich regionach i gminach nie jest zadaniem łatwym. Implementacja nowego podejścia w równoważeniu rozwoju wiąże się także z nieuchronnymi konfliktami kompetencyjnymi oraz zmianami w modelu funkcjonowania wielu istniejących instytucji. Oznacza to również podjęcie

\footnotetext{
* Wydział Biznesu, Finansów i Administracji, Uniwersytet Ekonomiczny w Katowicach.

** Wydział Ekonomii, Uniwersytet Ekonomiczny w Katowicach.

*** Wydział Ekonomii, Uniwersytet Ekonomiczny w Katowicach.
} 
przez władze samorządowe ogromnego wysiłku organizacyjnego i takie sterowanie procesami rozwoju, które pozwoliłoby na uzyskanie wielu efektów w poprawie warunków życia, efektywności inwestowania czy oszczędności finansowych związanych $z$ rozwojem infrastruktury. W wymiarze środowiskowym dla implementacji zrównoważonego rozwoju najistotniejszymi problemami i wyzwaniami są zmiany klimatu i adaptacja do tych zmian oraz utrzymanie niezbędnych do przeżycia usług świadczonych przez ekosystemy. Usługi ekosystemowe stanowią ważne ramy łączące infrastrukturę ekologiczną z infrastrukturą społeczną w mieście, co może przynieść korzyść ludziom i ekosystemom. Projektowanie, planowanie i zarządzanie złożonymi systemami miejskimi dla zdrowia i dobrego samopoczucia wymaga, aby ekosystemy miejskie były odporne na zmiany systemowe i były zarządzane w sposób zrównoważony. Z przeglądu literatury wynika fakt, że dotychczas stosunkowo niewielu badaczy skupiło się na badaniach oceniających miejskie usługi ekosystemowe (UES). Biorąc pod uwagę, że ponad połowa ludności świata mieszka w miastach, kluczowe znaczenie ma zrozumienie dualizmu zależności: skali dostarczania i zapotrzebowania na miejskie usługi ekosystemowe. Są to zarazem: nowe pola badawcze dla naukowców i nowe wyzwania dla polityków lokalnych kreujących praktyczne rozwiązania w tym zakresie. Wyniki przeprowadzonych przez autorów ${ }^{1}$ wcześniejszych badań wskazują na braki w tym zakresie oraz konieczność opracowania nowych rozwiązań dostosowanych i uwzględniających specyfikę regionalną i lokalną.

Celem artykułu jest próba oceny roli usług ekosystemów w miastach oraz polityce UE. Zidentyfikowano podstawowe uwarunkowania i bariery występujące przy praktycznym wdrażaniu koncepcji usług ekosystemowych w rozwoju lokalnym. Problematyka poruszana $\mathrm{w}$ referacie dotyczy także zaprezentowania rozwiązań dotyczących kreowania zintegrowanych systemów wspierania świadczenia tego rodzaju usług przez samorządy terytorialne.

Zastosowana w artykule metoda badawcza jest dostosowana do postawionych problemów badawczych, a przeprowadzone badania opierały się w równym stopniu na podejściu diagnostycznym i prognostycznym. Osiągnięcie postawionego celu wymagało analizy dorobku badawczego z zakresu usług ekosystemowych (określenie luk w teorii przedmiotu) oraz analizy polityk UE w tym zakresie.

1 E. Lorek, A. Lorek, Ochrona ustug ekosystemów jako komponent polityki spójności i zrównoważonego rozwoju miast śląskich, „Optimum. Studia Ekonomiczne” nr 1(79), 2016, s. 182-196. 


\section{Koncepcja usług ekosystemów w badaniach ze szczególnym uwzględnieniem obszarów miejskich}

Ewolucja podejścia do usług ekosystemowych datuje się od lat 70. XX w., kiedy to miało miejsce rozpoznanie związków między funkcjonowaniem ekosystemów i korzyściami czerpanymi przez społeczeństwo oraz sformułowanie zestawu funkcji ekosystemów wykorzystywanych przez człowieka. Samo pojawienie się terminu ecosystem services najczęściej wiąże się z publikacją w 1981 r. książki: P.R. Ehrlich, A.H. Ehrlich, Extinction: the causes and consequences of the disappearance of species ${ }^{2}$. Obecnie można zaobserwować rosnące zainteresowanie tą problematyką, a dyskusja zarówno na poziomie międzynarodowym ${ }^{3}$, jak i krajowym ${ }^{4}$ dotycząca aspektów teoretycznych i problemów definicyjnych jest wciąż niezakończona.

2 P.R. Ehrlich, A.H. Ehrlich, Extinction: the causes and consequences of the disappearance of species, Random House, New York 1981.

3 Por. R. Costanza, R. d'Arge, R. de Groot et al., The value of the world's ecosystem services and natural capital, „Nature” Vol. 387, 1997, s. 253-260 wraz z kontynuacją badań przedstawioną w: R. Costanza, R. de Groot, P. Sutton et al.,Changes in the global value of ecosystem services, "Global Environmental Change” No. 26, 2014, s. 152-158; R.S. de Groot, M.A. Wilson, R.M.J. Boumans, A typology for the classification, description and valuation of ecosystem functions, goods and services, „Ecological Economics” No. 41, 2002, s. 393-408; Y.E. Chee, An ecological perspective on the valuation of ecosystem services, „Biological Conservation" No. 120, 2004, s. 549-565; S. Farber, R. Constanza, D.L. Childers et al., Linking ecology and economics for ecosystem management, „Bioscience” No. 56, 2006, s. 121-133; J. Boyd, S. Banzhaf, What are ecosystem services? The need for standardized environmental accounting units, „Ecological Economics” Vol. 63 (2-3), 2007, s. 616-626, 639; K.J. Wallace, Classification of ecosystem services: problems and solutions, „Biological Conservation" No. 139, 2007, s. 235-246; R. Costanza, Ecosystem services: Multiple classification systems are needed, „Biological Conservation” No. 141, 2008, s. 350-351; B. Fisher, R.K. Turner, Ecosystem services: Classification for valuation, „Biological Conservation” No. 141, 2008, s. 1167-1169; B. Fisher, I. Bateman, R.K. Turner, Valuing Ecosystem Services: Benefits, Values, Space and Time, The United Nations Environment Programme, January 2011.

4 Por. A. Mizgajski, M. Stępniewska, Koncepcja świadczeń ekosystemów a wdrażanie zrównoważonego rozwoju, [w:] Ekologiczne problemy zrównoważonego rozwoju, red. D. Kiełczewski, B. Dobrzańska, Wydawnictwo WSE w Białymstoku, Białystok 2009, s. 12-23; A. Mizgajski, Świadczenia ekosystemów jako rozwijajace się pole badawcze i aplikacyjne, „Ekonomia i Środowisko” nr 1(37), 2010, s. 10-19; B. Poskrobko, Usługi środowiska jako kategoria ekonomii zrównoważonego rozwoju, „Ekonomia i Środowisko” nr 1(37), 2010, s. 20-30; T. Żylicz, Wycena ustug ekosystemów. Przeglą wyników badań światowych, „Ekonomia i Środowisko” nr 1(37), 2010, s. 31-45; A. Graczyk, Świadczenia ekosystemów jako dobra ekonomiczne, „Ekonomia i Środowisko" nr 1(37), 2010, s. 64-76; J. Solon, Koncepcja "Ecosystem Services” i jej zastosowania w badaniach ekologiczno-krajobrazowych, 2008, http://www.paek.ukw.edu.pl/wydaw/vol21/3_Solon_Koncepcja_ Ecosystem_Services.pdf [dostęp 9.12.2013]; A. Becla, S. Czaja, A. Zielińska, Pozaekonomiczne użytki środowiska przyrodniczego a ustugi ekosystemów w świetle współczesnego rachunku ekonomicznego, „Ekonomia i Środowisko" nr 2(45), 2013, s. 10-22; A. Mizgajski, A. Bernaciak, J. Kronenberg et al., Development of the ecosystem services approach in Poland, „Ekonomia i Środowisko” nr 51, 2014, s. 10-19; L.C. Braat, Ecosystem services: the ecology and economics of currentdebates, „Ekonomia i Środowisko” nr 51, 2014, s. 20-35; M. Degórski, J. Solon, Ecosystem services as a factor strengthening regional development trajectory, „Ekonomia i Srodowisko" nr 51, 2014, s. 48-57; J. Famielec, Benefits from Ecosystem Services versus Measures of Socioeconomic Development, „Ekonomia i Środowisko” nr 51, 2014, s. 58-67. 
Ciekawym elementem dyskusji naukowej w zakresie usług ekosystemowych jest ich część dotycząca roli i funkcjonowania ekosystemów na obszarach miejskich. Miasta są złożonymi systemami dostosowującymi się do nowych warunków, osadzonymi w jeszcze bardziej złożonych ekosystemach adaptacyjnych ${ }^{5}$. Ośrodki miejskie i otaczające je regiony są ośrodkami dla ludzi, infrastruktury i handlu, wymagającymi dużych zasobów oraz wywierającymi silną presję na środowisko ${ }^{6}$. Miasto jest środowiskiem życia dla większości populacji globalnej (>51\%), w tym blisko 80\% obywateli europejskich i amerykańskich. Ciągłe zwiększanie liczby i wielkości miast stwarza poważne wyzwania dla ograniczenia stopnia utraty różnorodności biologicznej i związanych z nimi funkcji ekosystemowych oraz zapewnienia dobrobytu ludności. Z badań milenijnych nad jakością ekosystemów wynika, że $60 \%$ ekosystemów środowiskowych jest zdegradowanych lub wykorzystywanych w sposób niezrównoważony, mających szkodliwe skutki dla ludzkiego samopoczucia ${ }^{7}$. Ponieważ człowiek wpływa na wszystkie ekosystemy i nie może bez nich istnieć, ochrona i zrównoważone użytkowanie ekosystemów nie są już wyizolowanymi polami zainteresowań, ale kluczowymi elementami zrównoważonego rozwoju na świecie. Obserwowane gwałtowne pogorszenie zdolności ekosystemów do generowania usług nie tylko wymaga lepszego zrozumienia, jak zachować ważne funkcje ekosystemowe, ale także wymaga, aby ta wiedza znalazła się w szerokim kontekście instytucjonalnym i zarządzania publicznego ${ }^{8}$. Aby rozwiązać problemy związane z degradacją ekosystemów, niezwykle istotne i w chwili obecnej konieczne jest interdyscyplinarne podejście do systemu społeczno-ekologicznego?.

Oceny jakości usług ekosystemów miejskich, ze szczególnym uwzględnieniem problematyki zielonej infrastruktury, były przedmiotem badań w ramach takich przedsięwzięć, jak „Milenijna Ocena Ekosystemów” ${ }^{10}$ oraz „Ekonomia Ekosystemów i Różnorodności Biologicznej"11. W Polsce szczególną uwagę do problematyki usług ekosystemowych w miastach przykłada Fundacja Sendzimira z siedzibą w Krakowie ${ }^{12}$.

5 T. Elmqvist, H. Setälä, S.N. Handel et al., Benefits of restoring ecosystem services in urban areas, „Current Opinion in Environmental Sustainability" Vol. 14, 2015, s. 101-108.

6 N.B. Grimm, S.H. Faeth, N.E. Gołubiewski et al., Global change and the ecology of cities, „Science” 319, 2008, s.756-760.

7 Ecosystems and human well-being: Synthesis, Millennium Ecosystem Assessment, Island Press, Washington, D.C. 2005.

8 Poradnik TEEB dla miast: usługi ekosystemów w gospodarce miejskiej, Fundacja Sendzimira, Kraków 2011.

9 C. Folke, S. Carpenter, B. Walker et al., Regime shifts, resilience, and biodiversity in ecosystem management, „Annual Review of Ecology Evolution and Systematics” Vol. 35, 2004, s. 557.

10 Ecosystems and human..., op.cit.

11 The Economics of Ecosystems and Biodiversity Ecological and Economic Foundations, red. P. Kumar, Earthscan, London and Washington 2010.

12 Patrz http://sendzimir.org.pl/, a w szczególności: Przyroda w mieście. Usługi ekosystemów - niewykorzystany potencjat miast. Polski poradnik TEEB dla miast, red. T. Bergier, J. Kronenberg, S. „Zrównoważony 
Oceniając dotychczasowy dorobek naukowy dotyczący miejskich usług ekosystemowych w wymiarze międzynarodowym, można stwierdzić, że większość badań poświęconych temu tematowi koncentrowała się na pojedynczych usługach ekosystemowych i/lub próbie wyceny. Dotychczasowy przegląd badań nad znaczeniem usług ekosystemowych na poziomie lokalnym wykazał, że brak jest zarówno historycznych studiów, jak i opracowań pokazujących rozwój tych usług w ujęciu dynamicznym. Prowadzone badania najczęściej dotyczyły usług zaopatrzeniowych, a w mniejszym stopniu regulujących i kulturalnych. Braki dotyczą badań nad synergią i kompromisem między różnymi rodzajami usług ekosystemowych. Natomiast można stwierdzić, że istnieje wiele badań nad metodologią wartościowania usług ekosystemowych ze wskazaniem na ich wykorzystanie w zarządzaniu miastem. Istotna luka badawcza dotyczy także wymiaru przestrzennego badań. Większość istniejących opracowań nad miejskim wymiarem usług ekosystemowych przeprowadzono w Europie Zachodniej (szczególnie Niemcy, kraje skandynawskie, Wielka Brytania, Hiszpania), Ameryce Północnej (USA) i Chinach, z rosnącą liczbą takich badań od roku 1975. Istotne braki dotyczą badań nad miejskim wymiarem usług ekosystemowych na kontynencie afrykańskim, państwach Europy Środkowowschodniej (państwa byłego bloku socjalistycznego) oraz Azji, ze szczególnym uwzględnieniem jej południowo-wschodniej częścici ${ }^{13}$.

\section{Problematyka usług ekosystemów w polityce UE}

Polityka Unii Europejskiej wspiera zrównoważony rozwój na poziomie lokalnym, w tym szczególnie działania na rzecz poprawy jakości środowiska i ochrony zasobów przyrodniczych, promowania strategii niskoemisyjnych, efektywnego wykorzystania ograniczonej przestrzeni (ze szczególnym uwzględnieniem potrzeby rekultywacji i rewitalizacji obszarów zdegradowanych). W ostatnich latach unijna polityka ochrony środowiska, np. siódmy program działań w zakresie środowiska naturalnego (siódmy EAP) i „Strategia różnorodności biologicznej do 2020 r”., zmieniły się w kierunku bardziej systemowej perspektywy zarządzania środowiskiem, wyraźnie

Rozwój - Zastosowania” nr 3, Fundacja Sendzimira, Kraków 2012; Przyroda w mieście - rozwiazania, red. T. Bergier, J. Kronenberg, P. Lisicki, S. „Zrównoważony Rozwój - Zastosowania” nr 4, Fundacja Sendzimira, Kraków 2013; Woda w mieście, red. T. Bergier, J. Kronenberg, I. Wagner, S. „Zrównoważony Rozwój - Zastosowania" nr 5, Fundacja Sendzimira, Kraków 2014; Poradnik TEEB dla miast: usługi ekosystemów w gospodarce miejskiej, Fundacja Sendzimira, Kraków 2011.

13 D. Haase, N. Larondelle, E. Andersson et al., A Quantitative Review of Urban Ecosystem Service Assessments: Concepts, Models, and Implementation, „Ambio” 43(4), 2014, s. 413-433. 
odnoszącej się do kapitału naturalnego. Na przykład priorytetowym celem siódmego EAP jest „ochrona, zachowanie i wzmocnienie kapitału naturalnego Unii”. Istnieje wiele synergii i korzyści związanych z bardziej zintegrowanym podejściem do zarządzania środowiskiem. Obecnie za najbardziej perspektywiczne uznaje się wdrażanie podejścia do planowania rozwoju i bieżącego zarządzania opartego na usługach ekosystemowych oraz biorącego pod uwagę cały ekosystem, w tym ludzi. Zarządzanie w oparciu o ekosystemy jest bardzo ważnym elementem podejścia zintegrowanego. Celem jest zachowanie zdrowych, czystych, wydajnych i trwałych ekosystemów, dzięki czemu mogą one dostarczać usługi i korzyści, od których zależy ludzki byt. Zarządzanie w oparciu o ekosystemy ma charakter przestrzenny i uwzględnia powiązania, skumulowane skutki i wielorakie cele istniejące w danej dziedzinie. Na tym właśnie polega różnica między zarządzaniem w oparciu o ekosystemy a podejściem tradycyjnym, koncentrującym się na pojedynczych problemach, np. dotyczących gatunków, konkretnych sektorów lub działań. Wdrożenie takiego podejścia do zarządzania działalnością człowieka - już stosowanego w odniesieniu do środowiska wodnego oraz rozwoju zielonej infrastruktury - dostarczy ważnych dowodów i wiedzy, na których podstawie będzie możliwe komunikowanie szerszego zastosowania długoterminowych, wzajemnie powiązanych rozwiązań odnoszących się do systemowych problemów dotyczących środowiska. Zintegrowane podejście do zarządzania daje również możliwość korekty dotychczasowego podejścia do gospodarki i rozwoju tzn. rezygnacji z przypisania kapitałowi wytworzonemu najwyższego priorytetu w stosunku do kapitału ludzkiego, społecznego i naturalnego. Złożony charakter degradacji ekosystemów (wiele przyczyn, kierunków zmian i skutków, które są trudne do rozdzielenia) utrudnia ujęcie w polityce działań i koncepcji odporności ekologicznej ${ }^{14}$.

Nadal istnieje wiele niewiadomych dotyczących stanu ogółem i trendów zmian różnorodności biologicznej w Europie oraz tego, jak się to odnosi do funkcjonowania ekosystemów i długoterminowego dostarczania usług ekosystemowych. Dostępne informacje o chronionych gatunkach i siedliskach dają jednak powody do niepokoju. $\mathrm{Z}$ raportu obejmującego lata 2007-2012, sporządzonego zgodnie z art. 17 dyrektywy siedliskowej, wynika, że zaledwie $23 \%$ gatunków zwierząt oraz roślin i tylko 16\% typów siedlisk przyrodniczych można uznać za znajdujące się we właściwym stanie ochrony ${ }^{15}$. Osiągnięcie znaczącej i wymiernej poprawy stanu gatunków i siedlisk będzie wymagało pełnego i skutecznego wdrożenia „Strategii na rzecz różnorodności biologicznej do 2020 r." i przepisów UE dotyczących ochrony przyrody.

14 Środowisko Europy 2015 - Stan i prognozy: Synteza, Europejska Agencja Środowiska, Kopenhaga 2015, s. 54 .

15 Ibidem, s. 57. 
Będzie to również wymagało spójności pomiędzy odpowiednimi politykami sektorowymi i regionalnymi (np. rolnictwa, rybołówstwa, rozwoju regionalnego i spójności, leśnictwa, energii, turystyki, transportu i przemysłu). W związku z tym losy różnorodności biologicznej w Europie i opartych na niej usług ekosystemowych są ściśle powiązane ze zmianami polityki w tych obszarach ${ }^{16}$, z czym mamy do czynienia w ostatnich latach.

Od początku XXI w. koncepcja usług ekosystemowych rozpoczęła proces wchodzenia do programów politycznych na poziomie UE. Od 2009 r. opracowano jednolitą definicję i standaryzowaną typologię usług ekosystemowych w Unii Europejskiej, a mianowicie wspólną międzynarodową klasyfikację usług ekosystemowych „The Common International Classification of Ecosystem Services" (CICES) ${ }^{17}$. UE upoważniła do mapowania i oceny usług ekosystemowych program MAES - „Mapping and Assessment of Ecosystems and their Services". Program pilotażowy MAES to współpraca między Komisją Europejską, Europejską Agencją Ochrony Środowiska, wolontariatem państw członkowskich i miast oraz innymi zainteresowanymi stronami. Jego ostatecznym celem jest dostarczenie bazy wiedzy na temat polityki i zarządzania ekosystemami miejskimi poprzez analizę zielonej infrastruktury miejskiej, stanu ekosystemów miejskich i usług ekosystemowych. W maju 2016 r. został opublikowany czwarty raport dotyczący mapowania oraz oceny ekosystemów i ich usług dla ekosystemów miejskich. Czwarte sprawozdanie MAES zawiera wskazówki dotyczące mapowania i oceny miejskich ekosystemów oraz ramy wskaźnikowe do oceny stanu ekosystemów miejskich i usług przez nie świadczonych z poziomu europejskiego na poziom lokalny. Raport zawiera również studia przypadków z Barcelony, Cascais, Lizbony, Oeiras, Padwy, Rzymu, Poznania, Trento, Oslo i Utrechtu. Badanie to wykazało, że istnieją już próby wdrażania tej koncepcji w warunkach miejskich, a w szczególności ${ }^{18}$ :

1) polityka miejska coraz częściej wykorzystuje miejską zieloną infrastrukturę i rozwiązania oparte na przyrodzie w procesie planowania,

2) coraz większa liczba danych w wielu skalach przestrzennych staje się dostępna w celu wspierania tych polityk, zapewnienia podstaw, a także porównywania miast pod względem zasięgu i zarządzania ekosystemem miejskim.

Za kolejny element ważny dla ochrony usług na obszarach zurbanizowanych można uznać politykę miejską. Prowadzenie polityki miejskiej nie zostało jasno

16 Ibidem, s. 57.

17 R. Haines-Young, M. Potschin, Common International Classification of Ecosystem Services (CICES): Consultation on Version 4, August-December 2012, EEA 2013.

18 Mapping and Assessment of Ecosystems and their Services. Urban ecosystems 4th Report, Technical Report - 2016-102, European Commission 2016, s. 7. 
sprecyzowane jako obowiązek UE, lecz wiele z unijnych strategii politycznych jest realizowanych w miastach i przez same miasta. Miasta to miejsca, w których można najlepiej stawić czoła wielu globalnym wyzwaniom. Miasta są na przykład idealnie przygotowane do zmniejszenia zużycia energii i emisji $\mathrm{CO}_{2}$, ponieważ gęstość obszarów miejskich pozwala na bardziej energooszczędne formy mieszkalnictwa i transportu. Miasta mogą również przyczynić się do rozwiązań służących rozwiązaniu kryzysu różnorodności biologicznej oraz do rozwoju usług ekosystemowych. W lipcu 2015 r. Komisja Europejska rozpoczęła publiczne konsultacje na temat kluczowych elementów agendy miejskiej UE. W oparciu o te konsultacje Komisja Europejska wraz z państwami członkowskimi kształtowała agendę miejską uzgodnioną w 2016 r. w Amsterdamie ${ }^{19}$. Agenda miejska UE odnosi się do wyzwań rozwojowych w wymiarze miejskim w sposób praktyczny, m.in. proponuje pracę nad rozwiązaniami niskoemisyjnymi i zwiększającymi odporność miast na zmiany klimatu.

Pomimo wspomnianych sukcesów i postępów w zakresie włączania usług ekosystemowych do polityki należy zauważyć, że w rzeczywistości nie ma konkretnych ram politycznych UE dotyczących usług ekosystemowych. Zamiast tego koncepcja usług ekosystemowych mogłaby - i faktycznie jest już w pewnym stopniu niejawnie osadzona w istniejącej polityce dotyczącej przyrody i zasobów naturalnych ${ }^{20}$. Jednym $z$ istotnych powodów umiarkowanej integracji koncepcji ES jest powolne tempo tworzenia polityki i procesów rewizji oraz często stopniowe zmiany polityki. Aktualnie średni okres przeglądu polityki wynosi od sześciu do dziesięciu lat. W związku z tym pojawiają się jedynie ograniczone możliwości zmian. Nawet po rewizji polityki zmiana jest skomplikowanym i długotrwałym procesem politycznym z udziałem Komisji Europejskiej, Parlamentu Europejskiego i państw członkowskich.

\section{Praktyczne przykłady wykorzystania koncepcji usług ekosystemów w miastach europejskich}

Natura w miastach, jak już wspomniano, odgrywa kluczową rolę w systemach zurbanizowanych. Od dawna poszukiwano różnych sposobów włączenia natury do

19 Urban Agenda for the EU, Pact of Amsterdam, Agreed at the Informal Meeting of EU Ministers Responsible for Urban Matters on 30 May 2016 in Amsterdam, The Netherlands, http://ec.europa. eu/regional_policy/sources/policy/themes/urban-development/agenda/pact-of-amsterdam.pdf [dostęp 14.11.2017].

20 Mapping and Assessment of Ecosystems and their Services. An analytical framework for ecosystem assessments under Action 5 of the EU Biodiversity Strategy to 2020, Technical Report - 2013-067, European Commission 2013, s.16-18. 
struktury miasta i zachowania otaczającego krajobrazu. Wielu architektów krajobrazu starało się nie tylko poprawić wygląd miasta, ale także poprawić stan zdrowia i zapewnić miejsca do odpoczynku i rekreacji dla stłoczonej ludności miejskiej. Oprócz najczęściej akcentowanych korzyści kulturowych, jakie zapewniają ekosystemy mieszkańcom miast, kluczowe znaczenie dla zdrowia i dobrego samopoczucia mieszkańców mają inne rodzaje usług, takie jak oczyszczanie wody i powietrza. Zatem w wielu krajach świata podejmuje się próbę ich włączenia do obecnych planów i polityki jako podstawy do planowania rozwoju, polityki i zarządzania miastami.

Według literatury przedmiotu „miejskie usługi ekosystemowe” są definiowane „jako te dostarczane przez ekosystemy miejskie i ich składniki, natomiast za ekosystemy miejskie uznaje się te, na których zbudowana przez człowieka infrastruktura obejmuje znaczną część powierzchni lądowej, lub te, w których gęstość zaludnienia jest wysoka” ${ }^{21}$. Obejmują one wszystkie „zielone i niebieskie przestrzenie” na obszarach miejskich, w tym parki, cmentarze, place i ogrody, ogrody działkowe, lasy miejskie, tereny podmokłe, rzeki, jeziora i stawy. W dyskursie dotyczącym polityki publicznej ekosystemy miejskie są często przedstawiane jako „zielona infrastruktura”.

Rozwój badań i analiz w zakresie funkcji ekosystemów, a także opracowanie i udoskonalenie metod szacowania wartości ekonomicznej usług ekosystemów były i są aktualnie powodem zmian postaw wśród decydentów i polityków. W europejskich miastach można zauważyć wiele dobrych praktyk w tym zakresie dotyczących: regulacji mikroklimatu, regulacji gospodarki wodami opadowymi poprzez zmniejszanie presji na system odwadniania i zmniejszenie ryzyka zalania przez wody opadowe; ograniczenia zanieczyszczeń i ich wpływu na zdrowie; ochrony siedlisk oraz różnorodności gatunków roślin i zwierząt jako istotnej cechy obszarów miejskich czy też dostarczania wystarczającej ilości usług kulturalnych. Podejście takie przekłada się na wyższą jakość życia mieszkańców i poprawę jakości środowiska, a w rozwiązaniach takich przodują państwa skandynawskie, w których zrównoważony rozwój jest podstawą planowania na poziomie lokalnym.

Warunkiem koniecznym do uwzględnienia usług ekosystemowych w polityce miejskiej jest ich wycena. Wycena miejskich usług ekosystemowych może polegać na określeniu wydajności usług ekosystemowych w ujęciu biofizycznym. Trudność w ocenianiu usług ekosystemowych w ujęciu biofizycznym wzrasta wraz ze zmianami rodzajów świadczonych usług, od zaopatrujących, przez regulacyjne, siedliskowe, do usług kulturalnych. W związku z tym, że większość usług zaopatrzeniowych i niektóre

21 S.T.A. Pickett, M.L. Cadenasso, J.M. Grove et al.,Urban ecological systems: linking terrestrial ecological, physical, and socioeconomic components of metropolitan areas, „Annual Review of Ecology Evolution and Systematics" Vol. 32, 2001, s. 127-157. 
regulacyjne mogą być zmierzone przez miary bezpośrednie, takie jak tony żywności na hektar rocznie lub tony sekwestrowanego węgla w przeliczeniu na hektar rocznie, w większości wypadków pomiar w terminach biofizycznych obejmuje wykorzystanie miar reprezentacyjnych i wskaźników ${ }^{22}$. Biofizyczne miary usług ekosystemowych są często prezentowane jako warunek wstępny dla wycen ekonomicznych, które ze względu na obszerność tematu nie zostaną zaprezentowane w artykule.

Przykładem praktycznego zastosowania podejścia opartego na wycenie usług ekosystemów miejskich jest miasto Berlin. W Berlinie podjęto próbę stworzenia wskaźnika Biotope Area Factor (BAF), który został opracowany w latach 90. $\mathrm{w}$ celu podjęcia działań dotyczących zwiększenia powierzchni przestrzeni zielonych w mieście. Głównym motorem opracowania tych działań była potrzeba zmniejszenia wpływu miasta na środowisko poprzez kompensację obecnych deficytów zieleni w otwartej przestrzeni. Według wskaźnika BAF można dokonać klasyfikacji powierzchni gruntów w zależności od ich potencjału ekologicznego (obliczany jest współczynnik powierzchni biotopu dla dzielnicy, tj. obszar powierzchni działek, które są pokryte roślinnością lub pełnią inne funkcje ekosystemowe, w odniesieniu do całkowitej powierzchni działki, zgodnie z założeniami przyjętymi w Berlinie) ${ }^{23}$. Na podstawie uzyskanych wyników formułowane są docelowe wskaźniki BAF dla określonych funkcji miejskich, których respektowanie jest wymagane wobec deweloperów (konieczne do uzyskania pozwolenia na budowę nowych inwestycji). Metodologia może być również wykorzystywana w innych miastach, ponieważ nie zależy od konkretnych uwarunkowań dotyczących miasta pochodzenia. Wskaźnik BAF przyczynia się zatem do ujednolicenia i określenia konkretnych celów w sferze jakości środowiska w zakresie:

- ochrony i poprawy mikroklimatu oraz higieny atmosferycznej,

- ochrony i rozwoju funkcji gleby oraz równowagi wód,

- tworzenia i poprawy jakości siedlisk roślinnych oraz zwierzęcych,

- poprawy środowiska mieszkalnego.

Każda poprawa istniejącego wskaźnika BAF jest uznawana za ważną, gdyż nawet niewielka zmiana przynosi różnicę w usługach ekosystemowych na danym obszarze ${ }^{24}$.

Metodę berlińską rozwijano również w innych miastach, w tym w Sztokholmie. W tym mieście zastosowano tzw. metodologię Grönytefaktor - GYF (inaczej:

22 E. Gómez-Baggethun, Å. Gren, D.N. Barton et al.,Urban ecosystem services, [w:] Urbanization, Biodiversityand Ecosystem Services: Challenges and Opportunities, red. T. Elmqvist, M. Fragkias, J. Goodness et al., Springer, Dordrecht-Heidelberg-New York-London 2013, s. 190.

23 Guidelines for Berlin Green module (BAF), Nov. 8, 2016, http://ecodistr-ict.eu/wiki/berlin-greenmodule-baf/ [dostęp 12.07.2017].

24 A. Kazmierczak, J. Carter, Adaptation to climate change using green and blue infrastructure. A database of case studies, 2010, http://www.mcrit.com/ADJUNTS/ciutats_sostenibles/berlin2.pdf [dostęp 11.11.2017]. 
Stockholm Biotope Area Factor). Metodologia GYF stosowana w Sztokholmie jest bardziej zaawansowanym narzędziem niż narzędzie stosowane w Berlinie. Zawiera wiele innych parametrów wejściowych i analizuje wiele aspektów zieleni miejskiej. Wymagane dane są bardziej szczegółowe i dotyczą dłuższych okresów potrzebnych do zbadania i zebrania danych, podczas gdy BAF jest procedurą dużo prostszą. Sztokholm GYF dostarcza użytkownikowi znacznie więcej informacji na temat zieleni w mieście i stanu ekosystemów w dzielnicy. Wskaźnik sztokholmski GYF promuje zieleń, która pełni kilka funkcji, np. stwarza zielone przestrzenie do rekreacji, opóźnia odpływ i oczyszcza wody deszczowe, zapewnia cień i przyczynia się do zapylania roślin oraz jest istotna dla celów estetycznych. GYF jest mierzony jako stosunek ekologicznej powierzchni do całkowitej powierzchni okręgu (dzielnicy). Ekologiczna powierzchnia składa się z wszystkich obszarów „zielonych i niebieskich” w obrębie dzielnicy zaprojektowanej zgodnie z określonymi wymaganiami. „Niebieskie” powierzchnie odnoszą się do obiektów związanych z zarządzaniem wodami deszczowymi, np. stawami, rowami i ogrodami deszczowymi. Wyniki są przedstawione jako stosunek powierzchni ekologicznie efektywnej do całkowitej powierzchni dzielnicy, a cele powinny zostać określone przez zainteresowane strony ${ }^{25}$.

Pomimo istniejących i przytoczonych przykładów dobrych praktyk stan ekosystemów miejskich w Europie wciąż budzi obawy. Przykładowo, według zgromadzonych przez Europejską Agencję Środowiska danych za lata 2007-2013 stan ochrony gatunków na terenach zurbanizowanych uznaje się za właściwy jedynie w około $20 \%$ przypadków, za niewłaściwy w ponad $60 \%{ }^{26}$. Dlatego też konieczna jest intensyfikacja działań w tym zakresie. Władze miejskie, chcąc kierować się zasadami zrównoważonego rozwoju obszarów miejskich i ochroną usług ekosystemowych niezbędnych do ich funkcjonowania, powinny rozważyć takie kierunki działań, jak ${ }^{27}$ :

1) Ochrona obszarów cennych przyrodniczo znajdujących się wokół zwartego obszaru miejskiego. Szczególnie istotnym instrumentem, który może być w tym zakresie wykorzystywany przez władze miejskie, jest właściwe planowanie przestrzenne i niezabudowywanie obszarów mogących świadczyć istotne usługi dla mieszkańców miast.

2) Zagospodarowanie wód opadowych w miejscu wystąpienia opadu, wdrażanie zdecentralizowanych systemów zagospodarowania wód deszczowych i roztopo-

25 Guidelines for Stockholm Green module (GYF), Nov. 10, 2016, http://ecodistr-ict.eu/wiki/stockholmgreen/ [dostęp 12.08.2017].

26 Środowisko Europy 2015..., op.cit., s. 58.

27 A. Lorek, Polityka zrównoważonego rozwoju gmin śląskich, „Zeszyty Naukowe UE w Krakowie” nr 1(961), 2017, s. 33-34. 
wych opartych na miejscowej retencji, infiltracji, oczyszczaniu oraz ponownym wykorzystaniu wód opadowych; szersze wykorzystanie „zielonej infrastruktury”.

3) Ochrona zieleni miejskiej, która jest istotnym czynnikiem wpływającym na jakość życia mieszkańców oraz tworzącym środowisko do życia i rozwoju innych gatunków.

Wymienione obszary działań nie zamykają katalogu potencjalnych aktywności ze strony władz miejskich, lecz odpowiadają na najistotniejsze problemy miast w tym zakresie (np. zabudowywanie i uszczelnianie powierzchni miejskich, likwidacja obszarów zielonych i/lub wycinka drzew i zakrzewień).

\section{Podsumowanie}

Utrata ekosystemów w miastach może wiązać się z wysokimi długoterminowymi kosztami ekonomicznymi i poważnym wpływem na wartości społeczne, kulturowe i ubezpieczeniowe związane $\mathrm{z}$ ich usługami. Koszty ekonomiczne związane z utratą ekosystemów miejskich wynikają z konieczności przywrócenia i utrzymania usług publicznych i dostaw poprzez budowaną przez człowieka zieloną infrastrukturę. Dalsze negatywne skutki wynikają ze skutków w wartościach społecznych i kulturowych, w tym poczucia miejsca, tożsamości i społeczności, spójności społecznej i lokalnej wiedzy ekologicznej. Utrata zielonej infrastruktury może również zwiększać podatność miast na wstrząsy, takie jak fale upałów, powodzie, burze, osuwiska, a nawet kryzysy żywnościowe. Mimo że obliczenia ekonomiczne dostarczają użytecznych argumentów na rzecz poprawy stanu środowiska, są niewystarczające do pełnego wychwytywania, pomiaru lub monitorowania zakresu korzyści związanych z przywracaniem usług ekosystemowych w miastach. Wiele ważnych usług ekosystemowych nie zostało wziętych pod uwagę w opublikowanych do tej pory badaniach. Potrzebne jest wiele dalszych prac, aby odpowiednio uchwycić i zwizualizować te wartości.

Inwestowanie w przywracanie, ochronę i poprawę infrastruktury ekologicznej oraz usług ekosystemowych w miastach jest nie tylko pożądane ekologicznie, ale i społecznie. Jest to również bardzo często opłacalne ekonomicznie, nawet przy użyciu dominujących modeli ekonomicznych, pod warunkiem, że zakres oraz wartość świadczeń ekosystemów i wszystkie związane z nimi korzyści dla dużej liczby beneficjentów w miastach są odpowiednio określone i uznawane. Takie informacje są niezbędne do włączenia się w procesy decyzyjne związane $\mathrm{z}$ użytkowaniem gruntów i zarządzaniem nimi w krajobrazach miejskich. Mogą również pomagać 
w planowaniu urbanistycznym i krajobrazowym architektom, inwestorom i decydentom oraz politykom, a także osobom prywatnym i instytucjom.

Szeroko zakrojone badania nad wartością zintegrowanych usług ekosystemowych pozwolą na wypracowanie modelu polityki środowiskowej na szczeblu lokalnym zapewniającego trwałość rozwoju lokalnego i regionalnego uwzględniającego zasady ochrony środowiska i jego zasobów. Aktualnie prace nad takim kształtem polityki zostały już zapoczątkowane, zarówno na szczeblu UE, jak i na poziomie lokalnym. Miasta są jednym z głównych podmiotów polityki, ponieważ bezpośrednio lub pośrednio realizują zasady polityki europejskiej w terenie, a tym samym przyczyniają się do urzeczywistniania głównych celów politycznych UE. Zauważono zatem potrzebę działań na poziomie UE, krajowym i miejskim, aby zapewnić miastom możliwość wykorzystania ich potencjału. Pomimo istniejących postępów problematyka usług ekosystemowych na obszarach miejskich jest wciąż słabo ukształtowanym polem badawczym oraz elementem polityki niedocenianym przez wiele samorządów miejskich. Przyszłe badania nad usługami ekosystemowymi powinny przede wszystkim dotyczyć opracowania zintegrowanych modeli usług ekosystemowych powiązanych z aspektami gospodarczymi i jakością życia. Należy ujednolicić metody oceny usług ekosystemowych zarówno po stronie podażowej, jak i po stronie popytu. Strona popytowa pozostaje w dużej mierze niezbadana. Niezbędne jest zatem opracowanie wskaźników i metod oceny wartości usług ekosystemowych. Wskaźniki po stronie popytu powinny zawsze zawierać dane społeczno-gospodarcze, bo są wysoce podatne na zmiany demograficzne i populacyjne oraz na wzorce mobilności na obszarach miejskich i wiejskich. Należy również wykorzystać ocenę wielokryterialną jako narzędzie do analizy relacji między człowiekiem a środowiskiem.

\section{Literatura}

Becla A., Czaja S., Zielińska A., Pozaekonomiczne użytki środowiska przyrodniczego a usługi ekosystemów w świetle wspólczesnego rachunku ekonomicznego, „Ekonomia i Środowisko" nr 2(45), 2013.

Biznes ekologiczny. Ekorynek, ekokonsument, ekostrategie gmin, red. E. Lorek, Wydawnictwo UE w Katowicach, Katowice 2015.

Boyd J., Banzhaf S., What are ecosystem services? The need for standardized environmental accounting units, „Ecological Economics” Vol. 63 (2-3), 2007.

Braat L.C., Ecosystem services: the ecology and economics of current debates, „Ekonomia i Środowisko" nr 51, 2014. 
Chee Y.E., An ecological perspective on the valuation of ecosystem services, „Biological Conservation" No. 120, 2004.

Costanza R., Ecosystem services: Multiple classification systems are needed, „Biological Conservation" No. 141, 2008.

Costanza R., d'Arge R., de Groot R., Farber S., Grasso M., Hannon B., Limburg K., Naeem S., O'Neill R.V., Paruelo J., Raskin R.G., Sutton P., van den Belt M., The value of the world's ecosystem services and natural capital, „Nature” Vol. 387,1997.

Costanza R., de Groot R., Sutton P., van der Ploeg S., Anderson S.J., Kubiszewski I., Farber S., Turner R.K., Changes in the global value of ecosystem services, „Global Environmental Change" No. 26, 2014.

Degórski M., Solon J., Ecosystem services as a factor strengthening regional development trajectory, „Ekonomia i Środowisko” nr 51, 2014.

de Groot R.S., Wilson M.A., Boumans R.M.J., A typology for the classification, description and valuation of ecosystem functions, goods and services, „Ecological Economics” No. 41, 2002.

Ecosystems and human well-being: Synthesis, Millennium Ecosystem Assessment, Island Press, Washington, D.C. 2005.

Ehrlich P.R., Ehrlich A.H., Extinction: the causes and consequences of the disappearance of species, Random House, New York 1981.

Elmqvist T., Setälä H., Handel S.N., van der Ploeg S., Aronson J., Blignaut J.N., Gómez-Baggethun E., Nowak D.J., Kronenberg J., de Groot R., Benefits of restoring ecosystem services in urban areas, „Current Opinion in Environmental Sustainability” Vol. 14, 2015.

European Social Progress Index, http://ec.europa.eu/regional_policy/en/information/ maps/social_progress

Famielec J., Benefits from Ecosystem Services versus Measures of Socioeconomic Development, „Ekonomia i Środowisko” nr 51, 2014.

Farber S., Constanza R., Childers D.L., Erickson J., Gross K., Grove M., Kahn C.S., Pinced S., Troy A., Warren P., Wilson M., Linking ecology and economics for ecosystem management, „Bioscience” No. 56, 2006.

Fisher B., Bateman I., Turner R.K., Valuing Ecosystem Services: Benefits, Values, Space and Time, The United Nations Environment Programme, January2011.

Fisher B., Turner R.K., Ecosystem services: Classification for valuation, „Biological Conservation" No. 141, 2008.

Folke C., Carpenter S., Walker B., Scheffer M., Elmqvist T., Gunderson L., Holling C.S., Regime shifts, resilience, and biodiversity in ecosystem management, „Annual Review of Ecology Evolution and Systematics" Vol. 35, 2004.

Fundacja Sendzimira, http://sendzimir.org.pl/ 
Giergiczny M., Kronenberg J., Jak wycenić wartość przyrody w mieście? Wycena drzew przyulicznych w centrum Łodzi, [w:] Przyroda w mieście. Usługi ekosystemów - niewykorzystany potencjat miast. Polski poradnik TEEB dla miast, red. T. Bergier, J. Kronenberg, S. „Zrównoważony Rozwój - Zastosowania” nr 3, Fundacja Sendzimira, Kraków 2012.

Gómez-Baggethun E., Gren Å., Barton D.N., Langemeyer J., McPhearson T., O’Farrell P., Andersson E., Hamstead Z., Kremer P., Urban ecosystem services, [w:] Urbanization, Biodiversity and Ecosystem Services: Challenges and Opportunities, red. T. Elmqvist, M. Fragkias, J. Goodness, B. Güneralp, P.J. Marcotullio, R.I. McDonald, S. Parnell, M. Schewenius, M. Sendstad, K.C. Seto, Springer, Dordrecht-Heidelberg-New York-London 2013.

Graczyk A., Świadczenia ekosystemów jako dobra ekonomiczne, „Ekonomia i Środowisko” nr 1(37), 2010.

Grimm N.B., Faeth S.H., Gołubiewski N.E., Redman C.L., Wu J., Bai X., Briggs J.M., Global change and the ecology of cities, „Science” 319, 2008.

Guidelines for Berlin Green module (BAF), Nov. 8, 2016, http://ecodistr-ict.eu/wiki/berlin-green-module-baf/

Guidelines for Stockholm Green module (GYF), Nov. 10, 2016, http://ecodistr-ict.eu/ wiki/stockholm-green/

Haase D., Larondelle N., Andersson E., Artmann M., Borgström S., Breuste J., Gomez-Baggethun E., Gren Å., Hamstead Z., Hansen R., Kabisch N., Kremer P., Langemeyer J., Lorance Rall E., McPhearson T., Pauleit S., Qureshi S., Schwarz N., Voigt A., Wurster D., Elmqvist T., A Quantitative Review of Urban Ecosystem Service Assessments: Concepts, Models, and Implementation, „Ambio” 43(4), 2014.

Haines-Young R., Potschin M., Common International Classification of Ecosystem Services (CICES): Consultation on Version 4, August-December 2012, EEA 2013.

Kazmierczak A., Carter J., Adaptation to climate change using green and blue infrastructure. A database of case studies, 2010, http://www.mcrit.com/ADJUNTS/ciutats_sostenibles/berlin ${ }^{2}$.pdf

Lorek A., Polityka zrównoważonego rozwoju gmin śląskich, „Zeszyty Naukowe UE w Krakowie" nr 1(961), 2017.

Lorek E., Lorek A., Ochrona usług ekosystemów jako komponent polityki spójności i zrównoważonego rozwoju miast śląskich, „Optimum. Studia Ekonomiczne” nr 1(79), 2016.

Mapping and Assessment of Ecosystems and their Services. An analytical framework for ecosystem assessments under Action 5 of the EU Biodiversity Strategy to 2020. Technical Report - 2013-067, European Commission 2013.

Mapping and Assessment of Ecosystems and their Services. Urban ecosystems 4th Report. Technical Report - 2016-102, European Commission 2016.

Mizgajski A., Świadczenia ekosystemów jako rozwijające się pole badawcze i aplikacyjne, „Ekonomia i Środowisko” nr 1(37), 2010. 
Mizgajski A., Bernaciak A., Kronenberg J., Roo-Zielińska E., Solon J., Śleszyński J., Development of the ecosystem services approach in Poland, „Ekonomia i Środowisko” nr 51, 2014.

Mizgajski A., Stępniewska M., Koncepcja świadczeń ekosystemów a wdrażanie zrównoważonego rozwoju, [w:] Ekologiczne problemy zrównoważonego rozwoju, red. D. Kiełczewski, B. Dobrzańska, Wydawnictwo WSE w Białymstoku, Białystok 2009.

Pickett S.T.A., Cadenasso M.L., Grove J.M., Nilon C.H., Pouyat R.V., Zipperer W.C., Costanza R., Urban ecological systems: linking terrestrial ecological, physical, and socioeconomic components of metropolitan areas, „Annual Review of Ecology Evolution and Systematics" Vol. 32, 2001.

Polityka zrównoważonego rozwoju gmin polskich. Studium przypadku woj. podlaskiego, wielkopolskiego i śląskiego, red. A. Lorek, A. Rączaszek, Wydawnictwo UE w Katowicach, Katowice 2016.

Poradnik TEEB dla miast: ustugi ekosystemów w gospodarce miejskiej, Fundacja Sendzimira, Kraków 2011.

Poskrobko B., Usługi środowiska jako kategoria ekonomii zrównoważonego rozwoju, „Ekonomia i Środowisko" nr 1(37), 2010.

Przyroda w mieście - rozwiąania, red. T. Bergier, J. Kronenberg, P. Lisicki, S. „Zrównoważony Rozwój - Zastosowania" nr 4, Fundacja Sendzimira, Kraków 2013.

Przyroda w mieście. Usługi ekosystemów - niewykorzystany potencjał miast. Polski poradnik TEEB dla miast, red. T. Bergier, J. Kronenberg, S. „Zrównoważony Rozwój - Zastosowania" nr 3, Fundacja Sendzimira, Kraków 2012.

Solon J., Koncepcja "Ecosystem Services" i jej zastosowania w badaniach ekologiczno-krajobrazowych, 2008, http://www.paek.ukw.edu.pl/wydaw/vol21/3_Solon_Koncepcja_ Ecosystem_Services.pdf

Środowisko Europy 2015 - Stan i prognozy: Synteza, Europejska Agencja Środowiska, Kopenhaga 2015.

The Economics of Ecosystems and Biodiversity Ecological and Economic Foundations, red. P. Kumar, Earthscan, London and Washington 2010.

Urban Agenda for the EU, Pact of Amsterdam, Agreed at the Informal Meeting of EU Ministers Responsible for Urban Matters on 30 May 2016 in Amsterdam, The Netherlands, http://ec.europa.eu/regional_policy/sources/policy/themes/urban-development/ agenda/pact-of-amsterdam.pdf

Wallace K.J., Classification of ecosystem services: problems and solutions, „Biological Conservation" No. 139, 2007.

Woda w mieście, red. T. Bergier, J. Kronenberg, I. Wagner, S. „Zrównoważony Rozwój - Zastosowania" nr 5, Fundacja Sendzimira, Kraków 2014.

Żylicz T., Wycena ustug ekosystemów. Przegląd wyników badań światowych, „Ekonomia i Środowisko" nr 1(37),2010. 


\section{Assessment of Urban Ecosystem Services in Sustainable Local Development}

Ecosystem services are an important framework for linking ecological infrastructure to urban social infrastructure, which can benefit people and ecosystems. Designing, planning and managing of complex urban systems for health and wellbeing requires urban ecosystems that are both immune to systemic changes and managed sustainably. Literature review reveals that so far only several researchers have focused on urban ecosystem services (UES). The paper aims at assessing the importance of ecosystem services at the local level with an emphasis on urbanized areas. The basic conditions and barriers to the implementation of the concept of ecosystem services in the EU policy and local development have also been identified. The paper also presents solutions concerning the creation of integrated systems of providing such services by local governments and their monitoring.

Keywords: urban ecosystems services, value of ecosystem services, EU policy

\section{L'évaluation des services écosystémiques dans les zones urbaines en tant que priorité de la politique de cohésion dans le développement local durable}

Les services écosystémiques constituent un cadre important reliant l'infrastructure écologique à l'infrastructure sociale de la ville, ce qui peuvent bénéficier aux individus et aux écosystèmes. Concevoir, planifier et gérer des systèmes urbains complexes pour apporter des avantages à la santé et au bien-être exige que les écosystèmes urbains soient résistants aux changements du système et gérées de manière durable. La revue de la littérature montre que jusqu'à présent, seuls quelques chercheurs se sont concentrés sur les recherches portant sur l'évaluation des services écosystémiques urbains (UES). Le but de cet article est de tenter d'évaluer l'importance des services écosystémiques au niveau local, avec un accent particulier mis sur les zones urbaines. On a aussi identifié les conditions de base et les obstacles dans la mise en œuvre pratique du concept des services écosystémiques dans la politique de l'UE et dans le développement local durable. Les questions abordées dans ce document concernent également la présentation de solutions pour la création de systèmes intégrés de ce type de services en vue d'être fourni par les autorités territoriales ainsi que les tentatives de les contrôler à l'aide d'indicateurs élaborés. 
Mots-clés: services écosystémiques urbains, valeur des services écosystémiques, politique de l'UE

\section{Оценка экосистемных услуг в городских районах как приоритета политики сплочения в устойчивом местном развитии и попытка их мониторинга}

Экосистемные услуги являются важной основой для увязки экологической инфраструктуры с городской социальной инфраструктурой, что может принести пользу людям и экосистемам. Проектирование, планирование и управление сложными городскими системами для здоровья и благополучия требует, чтобы городские экосистемы были невосприимчивы к системным изменениям и управлялись устойчиво. Обзор литературы показывает, что пока лишь несколько исследователей сосредоточились в своих работах на экосистемных услугах городской среды. Целью данной статьи является оценка важности экосистемных услуг на местном уровне, уделяя особое внимание урбанизированным районам. Были также определены основные условия и препятствия для реализации концепции экосистемных услуг в политике ЕС и в местном развитии. Обсуждаются также решения по создании интегрированных систем предоставления этого вида услуг местными органами власти и их мониторинг с помощью разработанных показателей.

Ключевые слова: экосистемные услуги городской среды, ценность экосистемных услуг, политика ЕС 